\title{
Molisch-positive Mucopolysaccharides of Gastric Cancers as Compared with the Corresponding Components of Gastric Mucosae
}

\author{
Third Report \\ On MPS (Mucopolysaccharide) II* \\ By \\ Hajime Masamune, Hiroya Kawasaki \\ (正宗 一) (川崎 裕 也) \\ and Sin-iti Abe \\ (阿 部 辰 $一$ ) \\ From the Medico-chemical Institute, Tohoku University, Sendai \\ (Received for publication, April 3, 1958)
}

This account deals with "MPSs II" of gastric cancer and of gastric mucosa which have been prepared as described in the Frist Report." They closely resemble each other regarding biological and physical properties. With respect to the chemical findings, however, it was noticed that glucosamine/galactosamine ratio and contents of glucose and of sialic acid are higher in the cancerous MPS II than in the non-cancerous, while the L-fucose contents of the two mucopolysaccharides are in reversed relationship. The other sugar components show almost no quantitative discrepancy between the two substances.

\section{EXPERIMENTAL}

Electrophoretic examination. As solvents were employed $0.1 M$ veronal$\mathrm{HCl}$ buffer, $\mathrm{pH} 8.6, \mathrm{I} 0.1+\mathrm{NaCl}(0.2 M)$ and $0.2 M$ acetate buffer of $\mathrm{pH}$ 4.6 $(\mathrm{I}=0.2)$. The substances gave single symmetric boundaries with nearly the same mobilities in either of the buffers. The boundary spreading of the cancerous mucopolysaccharide was pretty reversible. See Fig. 1.

Ultraviolet absorption. $50 \mathrm{mg} \%$ solutions ( $\mathrm{pH} 6.4$ ) were examined in a photoelectric spectrophotometer (EPB-U type, Hitachi). Cell $1 \mathrm{~cm}$. thick. The mucopolysaccharides gave both a spectrum with a low peak at $270 \mathrm{~m} \mu$, suggesting a trace of cyclic amino acids, but there occurred no particular absorption at $260 \mathrm{~m} \mu$ characteristic of nucleic acids. See Fig. 2.

* 217th report of Masamune and co-workers' "Biochemical Studies on Carbohydrates." Read before the XVIth General Meeting of the Japanese Cancer Association, Osaka, October 30-31, 1957. 

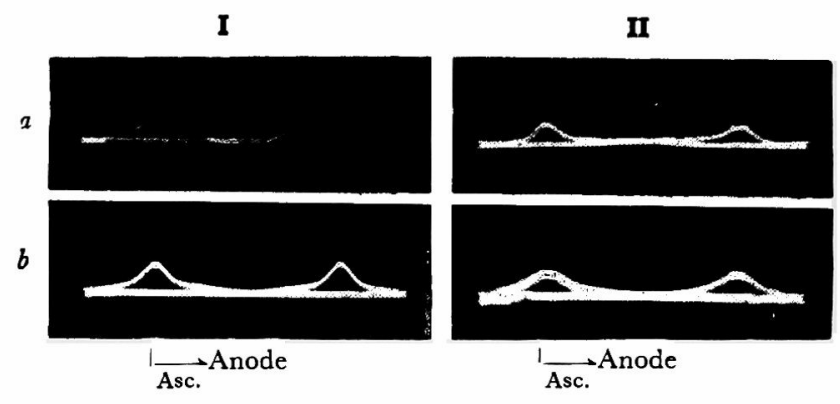

Fig. 1. Electrophoretic patterns $(2 / 3 \times)$ of $1 \%$ solutions of the cancerous (a) and non-cancerous (b) MPSs II in $0.1 \mathrm{M}$ veronal-HCl buffer of $\mathrm{pH} 8.6$ and I $0.1+\mathrm{NaCl}(0.2 M)(\mathbf{I})$ and $0.2 \mathrm{M}$ acetate buffer of $\mathrm{pH} 4.6$ (I 0.2$)$ (II). Current $8 \mathrm{~mA}$; temperature $15^{\circ} \mathrm{C}$; exposed $120 \mathrm{~min}$. after starting current. Mobilities in $\mathrm{cm}^{2} \cdot \mathrm{volt}^{-1} \cdot \mathrm{sec}^{-1} \times 10^{-5}$ :

Cancerous MPS II in veronal-HCl buffer $\frac{(-0.30) \times 0.01278 \times 0.3}{0.008 \times 7200}=-2.0$

$$
\text { in acetate buffer } \frac{(-0.10) \times 0.00588 \times 0.3}{0.008 \times 7200}=-0.3
$$

Non-cancernus MPS il in veronal-HCl buffer

$$
\begin{array}{r}
\frac{(-0.28) \times 0.01278 \times 0.3}{0.008 \times 7200}=-1.9 \\
\text { in acetate buffer } \frac{(-0.13) \times 0.00588 \times 0.3}{0.008 \times 7200}=-0.4
\end{array}
$$

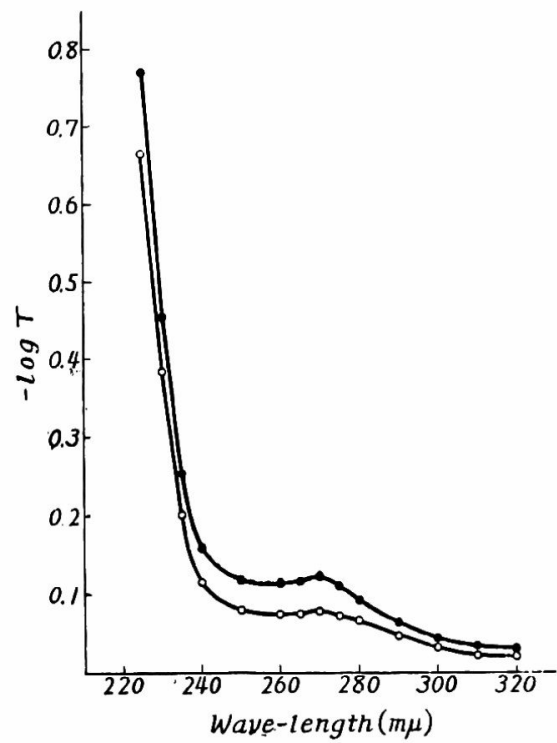

Fig. 2. Ultraviolet absorption spectra of aqueous $50 \mathrm{mg} \%$ solutions of the cancerous (-O-O-) and non-cancerous (-O-) MPSs II. 
Solubility. The two substances behaved similar also in this respect. They dissolve in water of any $\mathrm{pH}$ value, $90 \%(\mathrm{v} / \mathrm{v})$ phenol, saturated $\left(\mathrm{NH}_{4}\right)_{2} \mathrm{SO}_{4}$ (room temperature) and saturated $\mathrm{Na}_{2} \mathrm{SO}_{4}\left(33^{\circ} \mathrm{C}\right.$ ), and are not precipitated from water with lead acetate, cupric chloride, barium acetate, baryta and trichloroacetic acid. They are insoluble in glacial acetic acid, ethanol, acetone and ether.

Test-tube tests. No dissimilarity was found between the substances in the following test-tube tests. Molisch (\#), Bial (+), biuret (+), OsakiTurumi (direct as well as indirect) $(+)$, Neuberg-Saneyoshi $(-)$, Dische $(-)$, tests for phosphorus and hydrolysable sulfur (-).

Paper partition chromatography of components. 1) Sugars. $8 \mathrm{mg}$. substance was hydrolyzed with $1 \mathrm{~N} \mathrm{H}_{2} \mathrm{SO}_{4}$, and the hydrolysate chromatographed in a manner similar to the one in the Second Report. ${ }^{2)}$ Glactosamine, glucosamine, galactose, glucose, mannose and L-fucose were detected but no pentose in both of the substances from the cancerous and non-cancerous materials. See Fig. 3.

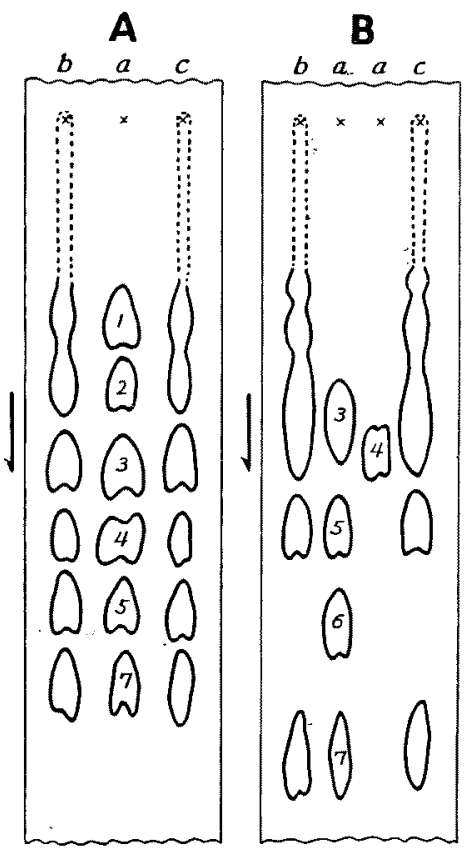

Fig. 3. Sugar paper chromatograms of MPSs II developed by descending irrigation with solvent butanol-pyridine-water (5:3:2 by volume) (A) or with solvent $n$ butylacetate-acetic acid-ethanol-water (3: $2: 1: 1$ by volume) (B) at $25^{\circ} \pm 1^{\circ} \mathrm{C}$ for 18 hrs. Paper slivers: Toyo Roshi filter paper No. 2, $10 \times 60 \mathrm{~cm}$. Spray reagent : $2 \%$ aniline phthalate in moist butanol. Reference runs were carried out using 0.02 cc. of $1 \%$ solutions with respect to individual sugars.

$a:$ reference run. $b:$ the hydrolysate of the cancerous MPS II. $c$ : the hydrolysate of the non-cancerous MPS II. 1 galactosamine, 2 glucosamine, 3 galactose, 4 glucose, 5 mannose, 6 xylose, $7 \mathrm{~L}$-fucose.

2) Amino acids. $6 \mathrm{mg}$. substance was subjected to $6 \mathrm{~N} \mathrm{HCl-hydroly-}$ sis and following operations described in the Second Report. ${ }^{2)}$ Fig. 4 is a reproduction of the chromatogram of the cancerous MPS II after hydrolysis. The hydrolysate of the non-cancerous MPS II gave a similar chromatogram. Namely, either of the two MPSs II proved to contain 
aspartic and glutamic acids, serine, glycine, hexosamine, lysine, histidine, arginine, threonine, alanine, tyrosine (weak spot), proline, valine and/or methionine and leucine and/or isoleucine and/or phenylalanine.

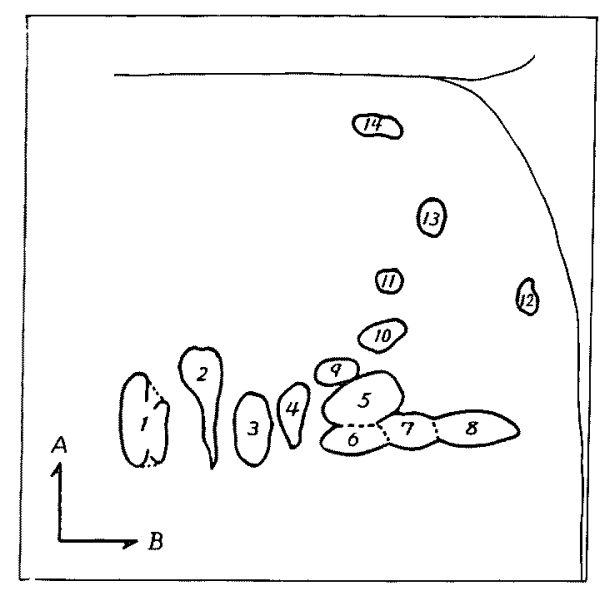

Fig. 4. Amino acid paper chromatogram of the cancerous MPS II. Paper square (Toyo Roshi filter paper No. 50) $30 \times 30 \mathrm{~cm}$. (A) Primary irrigation with solvent butanol-acetic acid-water ( $4: 1: 2$ by volume) (13 hrs., $25^{\circ} \pm 1{ }^{\circ} \mathrm{C}$ ). (B) Secondary irrigation with solvent $80 \%$ phenol in ammoniacontaining atmosphere $\left(13 \mathrm{hrs} ., 25^{\circ} \pm 1^{\circ} \mathrm{C}\right)$. Spray ragent $0.2 \%$ ninhydrin in moist butanol.

1 aspartic acid, 2 glutamic acid, 3 serine, 4 glycine, 5 hexosamine, 6 lysine, 7 histidine, 8 arginine, 9 threonine, 10 alanine, 11 tyrosine, 12 proline, 13 valine and/or methionine, 14 leucine and/or isoleucine and/or phenylalanine.

Quantitative analysis. The analytical figures obtained are embodied in Table I. Nitrogen-, total-hexosamine-, galactose- and mannose-contents and iodine uses don't noticeably differ between the cancerous and noncancerous MPSs II. On the contrary, glucosamine/galactosamine ratios and glucose-, sialic acid- and L-fucose-contents are discrepant from substance to substance, the cancerous MPS surpassing in the first three points and falling behind the non-cancerous in the last one point.

Optical rotation. The watery solutions examined were of $\mathrm{pH} 6.8$. The two substances were found levorotatory to resembling extents.

$$
\begin{aligned}
& \text { Cancerous MPS II }[\alpha]_{D}^{28}=\frac{-0.195 \times 1}{0.0100 \times 1}=-19.5^{\circ} \\
& \text { Non-cancerous MPS II }[\alpha]_{D}^{18}=\frac{-0.228 \times 1}{0.0120 \times 1}=-19.0^{\circ}
\end{aligned}
$$

Blood group potency. The glass plate method of Masamune et al. ${ }^{8)}$ was applied. The results are shown in Table II. The cancerous substance 
TABLE I

Composition of MPSs II of Stomach Cancer and of Stomach Mucosa

\begin{tabular}{|c|c|c|c|c|}
\hline \multirow{2}{*}{ Analysis } & \multicolumn{2}{|c|}{ In per cent } & \multicolumn{2}{|c|}{$\begin{array}{l}\text { In equivalents per } \\
\text { equivalent weight }\end{array}$} \\
\hline & $\begin{array}{l}\text { Stomach } \\
\text { cancer }\end{array}$ & $\begin{array}{c}\text { Stomach } \\
\text { mucosa }\end{array}$ & $\begin{array}{l}\text { Stomach } \\
\text { cancer }\end{array}$ & $\begin{array}{c}\text { Stomach } \\
\text { mucosa }\end{array}$ \\
\hline $\mathrm{N}^{*}$ & 5.3 & 5.6 & 3.63 & 3.68 \\
\hline Total hexosamine $\dagger$ & 27.0 & 28.9 & 1.44 & 1.48 \\
\hline$\frac{\text { Glucosamine }}{\text { Galactosamine }}$ ratio $†$ & 4.4 & 3.3 & & \\
\hline Galactose $\ddagger$ & 18.8 & 19.6 & 1.0 & 1.0 \\
\hline Glucoset & 7.3 & 2.9 & 0.39 & 0.15 \\
\hline Mannoseł & 6.3 & 6.7 & 0.34 & 0.34 \\
\hline L-Fucose§ & 6.9 & 10.8 & 0.40 & 0.61 \\
\hline Sialic acid// & 11.0 & 6.7 & 0.34 & 0.20 \\
\hline Asht & 2.1 & 1.6 & & \\
\hline Iodine use as glucose** & 5.2 & 5.2 & & \\
\hline
\end{tabular}

* Micro Kjeldahl. † Masamune and Yosizawa. ${ }^{8} \$$ Masamune and Sakamoto." \$ A modification of Dische and Shettles." // Direct Ehrlich reaction of Werner and Odin ${ }^{6}$ ) Calcd. as $\mathrm{C}_{11} \mathrm{H}_{19} \mathrm{NO}_{9}$. T Pregl method without use of conc. $\mathrm{H}_{2} \mathrm{SO}_{4}$, ** Macleod and Robison."

\section{TABLE II}

Anti-hemagglutinative Potency of MPSs II

Goat: normal anti-O goat serum. Anti-E : eel serum. Anti-OS : antiOS saliva chicken serum. - no hemagglutination, \pm faint hemaggl., + slight hemaggl., + marked hemaggl., H strong hemaggl.

\begin{tabular}{|c|c|c|c|c|c|c|c|c|c|c|c|c|c|}
\hline \multirow{2}{*}{ MPS II } & \multirow{2}{*}{$\begin{array}{l}\text { Red } \\
\text { cells }\end{array}$} & \multirow{2}{*}{ Serum } & \multicolumn{11}{|c|}{ Dilution of the substances $\left(1: 10^{3} \times\right)$} \\
\hline & & & 1 & 2 & 4 & 8 & 16 & 32 & 64 & 128 & 256 & 512 & $\infty$ \\
\hline \multirow{5}{*}{ Cancerous } & A & $\alpha$ & Ht & H & $H$ & \# & \# & $H$ & \# & \# & \# & H & H \\
\hline & B & $\beta$ & H & 世 & $H$ & H & H & H & 世 & 世 & $H$ & H & $H$ \\
\hline & $\mathrm{O}$ & Goat & + & \# & H & $H$ & H & \# & Ht & \# & $H$ & H & H \\
\hline & $O$ & Anti-E & H & \# & $H$ & $H$ & $世$ & H & H & H & 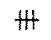 & \# & 世 \\
\hline & 0 & Anti-OS & H & $H$ & $H$ & $H$ & H & $H$ & H & H & $H$ & H & \# \\
\hline \multirow{5}{*}{ Non-canc. } & A & $\alpha$ & - & + & $H$ & \# & 卅 & $H$ & H & H & Ht & H & H \\
\hline & B & $\beta$ & + & $H$ & $H$ & \# & H & H & H & H & $\#$ & H & $H$ \\
\hline & 0 & Goat & - & H & $H$ & H & H & $H$ & H & \# & $H$ & H & Ht \\
\hline & $\mathrm{O}$ & Anti-E & \pm & $H$ & $H$ & $H$ & H & $H$ & Ht & 册 & $H$ & H & H \\
\hline & $\mathrm{O}$ & Anti-OS & - & - & $H$ & H & H & $H$ & $H$ & $H t$ & $H$ & $H$ & $H$ \\
\hline
\end{tabular}


TABLE III

Anemia-inducing Potency of MPSs II

\begin{tabular}{|c|c|c|c|c|c|c|c|c|c|c|c|c|}
\hline \multirow{3}{*}{ 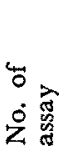 } & \multicolumn{3}{|c|}{ Rabbit } & \multirow{3}{*}{ 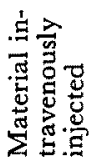 } & \multirow{3}{*}{ 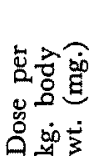 } & \multicolumn{7}{|c|}{ Number of red cells $\left(10^{4} \times\right.$; per cmm.) } \\
\hline & \multirow{2}{*}{ No. } & \multirow{2}{*}{$\begin{array}{l}\text { Body wt. } \\
\text { (kg.) }\end{array}$} & \multirow{2}{*}{ Sex } & & & \multirow{2}{*}{$\begin{array}{l}\text { Before } \\
\text { injec- } \\
\text { tion }\end{array}$} & \multicolumn{5}{|c|}{ Time after injection (hrs.) } & \multirow{2}{*}{$\begin{array}{c}\text { Maximum } \\
\text { decrease } \\
(\%)\end{array}$} \\
\hline & & & & & & & 1 & 2 & 3 & 4 & 5 & \\
\hline 1 & 7 & 2.2 & $\hat{\delta}$ & \multirow{5}{*}{ 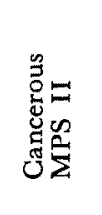 } & 1 & 746 & 745 & 725 & 723 & 751 & 712 & \multirow[t]{5}{*}{5} \\
\hline 2 & 8 & 2.7 & 우 & & $"$ & 585 & 607 & 592 & 608 & 613 & 596 & \\
\hline 3 & 9 & 2.7 & 今 & & 3 & 662 & 668 & 662 & 658 & 633 & 670 & \\
\hline 4 & 10 & 2.7 & $\hat{\rho}$ & & , & 679 & 694 & 651 & 645 & 678 & 653 & \\
\hline 5 & 11 & 2.3 & 今 & & $"$ & 652 & 664 & 674 & 647 & 621 & 625 & \\
\hline 6 & 12 & 2.5 & 今 & \multirow{3}{*}{ 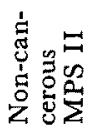 } & 3 & 639 & 654 & 643 & 638 & 632 & 622 & 3 \\
\hline 7 & 13 & 2.7 & 우 & & $"$ & 602 & 595 & 570 & 571 & 576 & 580 & 5 \\
\hline 8 & 14 & 2.3 & 우 & & " & 600 & 578 & 600 & 583 & 593 & 605 & 4 \\
\hline
\end{tabular}

T A B LE IV

Liver-catalase Depression in vivo of MPSs II

In each test-set, the average volume of $\mathrm{O}_{2}$ evolved for each dose is expressed in per cent of the corresponding volume of $\mathrm{O}_{2}$ in the blank control.

\begin{tabular}{|c|c|c|c|c|c|c|c|}
\hline \multirow{3}{*}{ No. of test-set } & \multirow{3}{*}{$\begin{array}{l}\text { No. of mice } \\
\text { used }\end{array}$} & \multicolumn{6}{|c|}{ Amount of the substances intraperitoneally injected (mg.) } \\
\hline & & \multicolumn{3}{|c|}{ Cancerous MPS II } & \multicolumn{3}{|c|}{ Non-cancerous MPS II } \\
\hline & & 5 & 3 & 1 & 5 & 3 & 1 \\
\hline 1 & 9 & & & 91 & & & 96 \\
\hline 2 & 15 & 90 & & 97 & 98 & & 97 \\
\hline 3 & 15 & 96 & 96 & & 103 & 100 & \\
\hline 4 & 15 & 90 & 97 & & 92 & 105 & \\
\hline
\end{tabular}

exhibited no group potency. That the non-cancerous was slightly inhibitory to the agglutination of $\mathrm{A}$ and $\mathrm{O}$ erythrocytes is most probably due to faint contamination with the very strong group mucopolysaccharide or mucopolysaccharides.

Anemia-inducing potency ( $K I K$ activity). It was examined as by Masamune and Kawasaki. ${ }^{9}$ As shown in Table III, the substances caused no more decrease than $5 \%$ of number of erythrocytes, even when injected into a rabbit in dosage of $3 \mathrm{mg}$. per $\mathrm{kg}$. body weight.

Toxohormone activity. It was determined according to Masamune and others $^{10)}$ (gasometry of catalase activity). Injection of even $5 \mathrm{mg}$. amounts of MPSs II did not entail depression of liver catalase in mice. See Table IV. 


\section{SUMmary}

1. MPSs II, cancerous and non-cancerous, in the First Report were examined physically, chemically and biologically.

2. They proved homogeneous electrophoretically and absorbed no ultraviolet light near $260 \mathrm{~m} \mu$.

3. They are made up of same components.

4. However, glucosamine/galactosamine ratio and contents of glucose, of sialic acid and of L-fucose vary from substance to substance.

5. Their optical rotations resemble each other.

6. They don't possess group activity within $\mathrm{ABO}$ classification. They are also devoid of KIK- and toxohormone-activity.

Through the Grant Committee for Scientific Researches the Ministry of Education gave a grant in aid to us, which is gratefully acknolwedged. $\mathrm{H}$. Masamune.

\section{References}

1) Masamune, Kawasaki, Abe, S., Oyama \& Yamaguchi, Tohoku J. Exp. Med., this volume, p. 81 .

2) Kawasaki, ibid., this volume, p. 119.

3) Masamune \& Yosizawa, ibid., 1957, 65, 169.

4) Masamune \& Sakamoto, ibid., 1956, 63, 345.

5) Masamune \& Kawasaki, ibid., 1956, 63, 369 (ff. 381-382).

6) Werner \& Odin, Acta soc. med. Upsal., 1952, 57, 230.

7) Macleod \& Robison, Bioch. J., 1929, 23, 517.

8) Masamune, Hakomori, Numabe, Akama \& Kamiyama, Tohoku J. Exp. Med., 1955, 61, 283.

9) Masamune \& Kawasaki, ibid., 1956, 63, 369 (f. 372).

10) Masamune, Tsuiki, Kamiyama, Abe, S., Haga, Kawasaki, Kaketa \& Abe, Sh., ibid., 1958, 67, 309. 